\title{
UPAYA REHABILITASI EKS PEKERJA SEKS KOMERSIAL (PSK) DI PANTI SOSIAL KARYA WANITA (PSKW) ANDAM DEWI SOLOK
}

\author{
1AHMAD SAEFULLOH, ${ }^{2}$ NOFRIZA \\ 1,2 Prodi Pendidikan Agama Islam, STIT AD Jambi \\ Email: ahmad.saifullah39@gmail.com
}

\author{
Article History: \\ Received: 2018-10-09; Received in revised form: 2018-10-23; Accepted: 2018-10-23; \\ Available online: 2018-10-26
}

\begin{abstract}
This study aims to see the rehabilitation efforts offormer Sex Workers Commercial (PSK) in Panti Sosial Karya Wanita (PSKW) Andam Dewi Solok. A large number of sex workers becomes a severe problem that must be followed up immediately. The Crowd raids prostitution reported in the media into the spotlight of the world of education in instilling moral education to learners. This is the importance of recognizing the negative impacts. To avoid the proliferation of the practice of prostitution is necessary for preventive and rehabilitative efforts against the perpetrators of prostitution practices that netted raids. This study aims to provide a form of preventive and rehabilitative efforts for the "eks PSK" who were caught raids in social institutions as well as to the general public. This research is a qualitative descriptive study. Data collection by observation method, direct interview, and documentation. Techniques used in data analysis are data display, data reduction, and conclusion. The data validity technique uses source triangulation. The results showed that: 1) preventive efforts that can be done include the formation of wirid adolescents and regular weekly recitation, 2) submission of grants through grant channeling institutions. While rehabilitative efforts include religious programs, skills, and crafts as well as long-term assistance.
\end{abstract}

Keywords: Efforts, Ex-PSK, Rehabilitation

\begin{abstract}
Abstrak
Kajian ini bertujuan melihat upaya rehabilitasi eks Pekerja Seks Komersial (PSK) di Panti Sosial Karya Wanita (PSKW) Andam Dewi Solok. Banyaknya para pekerja seks menjadi permasalahan serius yang harus segera ditindak lanjuti. Ramainya razia prostitusi yang diberitakan di media menjadi sorotan dunia pendidikan dalam menanamkan pendidikan moral kepada peserta didik. Hal ini merupakan pentingnya pengenalan dampak negatif yang ditimbulkan. Untuk menghindari semakin mewabahnya praktek prostitusi tersebut perlu adanya upaya preventif maupun rehabilitatif terhadap para pelaku praktek prostitusi yang terjaring razia. Penelitian ini bertujuan memberikan bentuk upaya preventif dan rehabilitatif bagi para "eks PSK" yang tertangkap razia di lembaga sosial sekaligus kepada masyarakat umum. Penelitian ini merupakan penelitian deskriptif kualitatif. Pengumpulan data dengan metode observasi, wawancara langsung dan dokumentasi. Teknik yang digunakan dalam analisis data adalah display data, reduksi data dan kesimpulan. Teknik keabsahan data menggunakan triangulasi sumber. Hasil penelitian menunjukan bahwa: 1) upaya preventifyang dapat di lakukan meliputi pembentukan wirid remaja dan pengajian rutin mingguan, 2) pengajuan dana bantuan usaha melalui lembaga penyalur dana hibah. Sedangkan upaya rehabilitatif meliputi program keagamaan, keterampilan dan kerajinan tangan serta pendampingan jangka panjang.
\end{abstract}

Kata Kunci; Eks PSK, Rehabilitasi, Upaya 


\section{PENDAHULUAN}

Salah satu bentuk kriminalitas yang meresahkan masyarakat saat ini adalah ramainya prostitusi, baik secara online maupun secara langsung, sehingga permasalahan tentang prostitusi tergolong sebagai permasalahan extra ordinary, yaitu permasalahan yang luar biasa dan sangat serius. Hampir setiap hari media masa memberitakan penangkapan para pekerja seks komersial atau sering dikenal dengan PSK yang tertangkap oleh Satpol PP melalui razia pekat yang mereka lakukan'1. Prostitusi atau pelacuran merupakan salah satu penyakit yang berkembang di dalam masyarakat. Penyakit ini sudah menjadi suatu fenomena sosial masyarakat yang sangat kompleks, mulai dari segi sebab, proses maupun implikasi sosial yang di timbulkannya. Prostitusi atau pelacuran adalah penjualan jasa seksual untuk uang. Seseorang yang menjual jasa seksual disebut dengan Pekerja Seks Komersial (PSK) bagi wanita dan gigolo bagi pria. Para pelaku perbuatan tersebut biasanya dikenal dengan tuna susila. Meskipun banyak prasangka negatif terhadap perbuatan pelacuran, namun prostitusi tetap tumbuh subur di dalam lingkungan masyarakat, sementara masyarakat kita menjunjung tinggi norma-norma dan nilai agama, (Hermansyah 2016) Berbagai elemen baik dari Instansi pemerintah pun telah melakukan upaya penertiban praktik prostitusi, namun praktik tersebut hanya berhenti sementara dan muncul kembali pada selang waktu berikutnya.

\section{METODE}

Penelitian ini merupakan penelitian deskriptif kualitatif. Pengumpulan data dengan metode observasi, wawancara langsung dan dokumentasi. Teknik yang digunakan dalam analisis data adalah display data, reduksi data dan kesimpulan. Teknik keabsahan data menggunakan triangulasi sumber.

Penelitian dilakukan di Panti Sosial Karya Wanita (PSKW) Andam Dewi Solok Selatan. Berdirinya Panti Sosial Karya Wanita (PSKW) Andam Dewi Solok merupakan rekomendasi Seminar Penyusunan Pola Induk Pembangunan Bidang Kesejahteraan Sosial Provinsi Sumatera Barat tahun 1977 agar dilakukan upaya antisipasi munculnya masalah Wanita Tuna Susila (WTS) di Minangkabau dan upaya penanggulangannya. Seminar ini diadakan karena terjaringnya 136 WTS pada razia pekat yang dilakukan pada tahun 1977/1978 di wilayah Sumatera Barat. Melihat keadaan ini Pemerintah Daerah mengusulkan kepada Pemerintah Pusat agar mendirikan Panti Sosial untuk rehabilitasi WTS yang terjaring di wilayah Sumatera Barat.

${ }^{1}$ Ani Purwanti, Dyah Wijaningsih Gunawan Prakoso*, 'KEBIJAKAN PEMERINTAH DAERAH DALAM MENANGGULANGI PROSTITUSI DI KABUPATEN BELITUNG PROVINSI BANGKA BELITUNG', Diponegoro Law Journal, 2016. 
Pemerintah pusat menyetujui pendirian panti sosial dengan pengadaan tanah seluas $2 \mathrm{Ha}$, setelah itu di lakukan penjajagan ke beberapa daerah di Sumatera Barat (Syahbana 2017). Akhirnya Gubernur Sumatera Barat menunjuk Desa Sukarami, Kec. Gunung Talang, Kab. Solok, sebagai tempat pembangunan panti rehabilitasi Wanita Tuna Susila. Daerah ini dipilih sebagai tempat didirikannya PSKW Andam Dewi dikarenakan jauh dari tempat keramaian. Selain lokasi yang strategis, juga telah adanya peraturan Gubernur Sumatera Barat Nomor 56 Tahun 2009 yang memperkuat pendirian Unit Pelaksana Teknis Dinas (UPTD) Panti Sosial Karya Wanita "Andam Dewi" Solok yang mempunyai tugas pokok melaksanakan sebagian teknis operasional dan/atau kegiatan teknis penunjang Dinas Sosial di bidang rehabilitasi terhadap wanita tuna susila. Berdasarkan bentuk kekhawatiran ini, perlu adanya upaya dalam mencegah dan mengatasi permasalahan prostitusi.

\section{DEFINISI PROSTITUSI}

Prostitusi atau juga disebut pelacuran berasal dari bahasa latin yaitu pro-situare yang berarti membiarkan diri berbuat zina, melakukan perbuatan persundalan, pencabulan, pergendakan. Dalam bahasa Inggris prostitusi disebut dengan prostitution yang artinya tidak jauh berbeda dengan bahasa latin yaitu pelacuran atau ketunasusilaan. Orang yang melakukan perbuatan prostitusi disebut pelacur yang dikenal dengan WTS (Wanita Tuna Susila) (Kartono 1997).

Istilah pelacuran dalam Kamus Besar Bahasa Indonesia berasal dari kata lacur yang berarti malang, celaka, sial, gugal, atau buruk laku. Pelacur adalah perempuan yang melacur, sehingga pelacuran merupakan perbuatan menjual diri sebagai pelacur atau penyundalan (Depdikbud 1984). Menurut William Benton dalam Encyclopedia Britanica, pelacuran dijelaskan sebagai praktek hubungan seksual yang dilakukan sesaat, yang kurang lebih dilakukan dengan siapa saja (promiskuitas) untuk imbalan berupa uang (Truong 1992). Sedangkan secara terminologis pelacuran atau prostitusi adalah penyediaan layanan seksual yang dilakukan oleh laki-laki atau perempuan untuk mendapat uang atau kepuasan (P.Masland 1987). Menurut Mulia, T.S.G dalam ensiklopedia Indonesia dijelaskan bahwa pelacuran itu bisa dilakukan baik oleh kaum wanita maupun pria. Jadi, ada persamaan predikat pelacuran antara laki-laki dan wanita yang bersama-sama melakukan perbuatan hubungan kelamin di luar perkawinan, dalam hal ini cabul tidak hanya berupa hubungan kelamin di luar nikah saja, akan tetapi termasuk pula peristiwa homoseksual dan permainan-permainan seksual lainnya (Kartono 1997).

Menurut masyarakat luas prostitusi atau pelacuran adalah persenggamaan antara pria dan wanita tanpa terikat piagam pernikahan yang 
$\mathrm{sah}^{2}$. Perbuatan ini dipandang rendah dari sudut moral dan akhlak, dosa menurut agama, tercela dan jijik menurut penilaian masyarakat di Indonesia. Akan tetapi pelacuran adalah salah satu profesi dan lahan bisnis untuk tujuan ekonomi (Mahfudz 1994). Berdasarkan uraian di atas, dapat disimpulkan bahwa paling tidak terdapat empat ciri utama dalam definisi prostitusi atau pelacuran yang dapat ditegakkan, yakni: bayaran, perselingkuhan, ketidakacuhan emosional, dan mata pencaharian. Dalam banyak definisi di atas dan pembahasan-pembahasan literatur lainnya bahwa uanglah yang menjadi sumber pendapatan dianggap faktor paling umum dalam dunia pelacuran. Perbuatan zina adalah salah satu di antara sebab-sebab dominan yang mengakibatkan kerusakan dan kehancuran peradaban, menularkan penyakit-penyakit yang sangat berbahaya, mendorong orang untuk terus menerus hidup membujang serta praktek hidup bersama tanpa nikah. (Sabiq 2009)

\section{LARANGAN “HUMAN TRAFICKING” BAIK LANGSUNG MAUPUN ONLINE}

Praktik prostitusi tidak hanya melibatkan orang dewasa saja, namun banyak di antaranya masih dalam usia remaja ${ }^{3}$. Sebagaimana yang disampaikan oleh Kabid Humas Polda Sumbar AKBP Syamsi bahwa di antara mereka yang ditemukan saat melakukan razia pekat di Taman Melati Padang adalah remaja yang berusia antara 15 hingga 22 tahun (Syamsi 2016). Usia tersebut masih dalam kategori usia anak yaitu 18 tahun ke bawah, sehingga melanggar undang-undang perlindungan anak tentang larangan eksploitasi seksual yang diatur dalam Pasal 1 angka 1 Undang-undang nomor 21 tahun 2007 tentang Pemberantasan Tindak Pidana Perdagangan orang, yaitu :"Tindakan perekrutan, pengangkutan, penampungan, pengiriman, pemindahan, atau penerimaan seseorang dengan ancaman kekerasan, penggunaan kekerasan, penculikan, penyekapan, pemalsuan, penipuan, dan penyalahgunaan kekuasaan atau posisi rentan, penjeratan uang atau memberikan bayaran atau manfaat, sehingga memperoleh persetujuan dari orang yang memegang kendali atas orang lain tersebut, baik yang dilakukan di dalam negara maupun antar negara untuk tujuan eksploitasi atau mengakibatkan orang tereksploitasi dapat dijatuhi hukuman penjara minimal 3 tahun dan maksimal 15 tahun (UU RI No. 35 Tahun 2014 2016).

2 Pambudi Handoyo Iis Susanti, 'Perilaku Menyimpang Dikalangan Remaja Pada Masyarakat Karangmojo Plandaan Jombang', Paradigma, 2015.

3 Febri Yanti, 'Dinamika Kecenderungan Gaya Hidup Hedonis Dan Perilaku Seks Bebas Pada Remaja Putri', Jurnal Ilmiah Mahasiswa Bimbingan \& Konseling, 2016. 
Perdagangan orang juga dapat dilakukan melalui jaringan internet (online) ${ }^{4}$. Prostitusi online di atur dalam beberapa Undang-undang, seperti Undang-undang RI No. 44 Tahun 2008 Pasal 1 ayat 1 dan 2 tentang pornografi menyebutkan "Pornografi adalah gambar, sketsa, ilustrasi, foto, tulisan, suara, bunyi, gambar bergerak, animasi, kartun, percakapan, gerak tubuh, atau bentuk pesan lainnya melalui berbagai bentuk media komunikasi dan/atau pertunjukan di muka umum yang memuat kecabulan atau eksploitasi seksual yang melanggar norma kesusilaan dalam masyarakat (UU RI No. 35 Tahun 2014 2016).

Ayat (1) di atas hanya sebatas penyabab terjadinya bentuk pencabulan dan eksploitasi seksual saja, namun terkait prostitusi undang-undang ini menyebutkan dengan jasa pornografi yang terdapat pada pasal 1 ayat (2) "Jasa pornografi adalah segala jenis layanan pornografi yang disediakan oleh orang perseorangan atau korporasi melalui pertunjukan langsung, televisi, kabel, televisi telesterial, radio, telepon, internet, dan komunikasi elektronik lainnya serta surat kabar, majalah, dan barang cetakan lainnya.

Praktik prostitusi yang diatur dalam undang-undang ini diperjelas pada pasal 4 ayat (2) huruf d tentang larangan serta pembatasan. Isi pasal tersebut adalah "Setiap orang dilarang menyediakan jasa pornografi yang menawarkan atau mengiklankan, baik langsung atau tidak langsung layanan seksual. Melihat pasal 1 ayat (2) dan pasal 4 ayat (2) di atas, maka prostitusi online dapat dipidanakan karena adanya unsur menawarkan jasa layanan seksual yang menampilkan unsur pornografi. Maka, pada pasal 7 Undangundang Pornografi ini lebih tegas lagi menindak pihak-pihak yang telibat dalam praktik prostitusi online yang isinya yaitu "Setiap orang dilarang mendanai atau memfasilitasi perbuatan sebagaimana dimaksud pada pasal 4 .

Pasal di atas melibatkan seluruh pihak-pihak yang terkait dengan pengguna internet, termasuk pemilik website, dan pemilik server (tempat bagi pemilik website menempatkan data-data berisikan konten-konten yang intinya menawarkan jasa pekerja seks komersial. Namun, meskipun sudah terdapat undang-undang yang melarang praktik prostitusi online ini, masih ditemukan kelemahan yaitu apabila pemilik server bukan dari kewarganegaraan Indonesia. Maka, dalam hal ini Indonesia harus menjalin perjanjian ekstradisi dengan negara asal pihak pemilik server, sehingga undang-undang ITE bisa diberlakukan bagi pihak prostitusi online di luar negara. Untuk pekerja seks komersial sendiri undang-undang pornografi menyebutkannya pada pasal 8, yaitu "Setiap orang dilarang dengan sengaja

${ }^{4}$ Ahmad Saifuddin, 'Abnormalitas Perilaku Pada Anak Dan Remaja, Sudah Sebegitu Parahnya??', Proceeding Seminar Nasional "Selamatkan Generasi Bangsa Dengan Membentuk Karakter Berbasis Kearifan Lokal”, 2015. 
atau atas persetujuan dirinya menjadi objek atau model yang mengandung muatan pornografi".

Maksud pasal di atas adalah melarang orang menjadikan dirinya objek yang bermuatan pornografi baik oleh diri sendiri maupun atas izinnya sendiri. Dalam praktik prostitusi online ada dua hal yang biasanya dilakukan pekerja seks komersial, ada yang dilakukan secara sendiri tanpa pihak yang memfasilitasi, ini terjadi pada media obrolan Internet seperti Yahoo Messenger, Facebook, Watshap, Line atau aplikasi jejaring sosial lainnya. Kemudian ada juga pihak yang ikut memfasilitasi transaksi seks seperti pada website, Blog dan forum-forum ruang internet lainnya. Pasal 8 undang-undang pornografi tersebut dapat diterapkan kepada kedua hal tersebut untuk menjerat pekerja seks komersial melalui media online.

\section{SANKSI PROSTITUSI DAN MUCIKARI}

Ketentuan sanksi-sanksi dalam undang-undang pornografi, diatur secara spesifik merujuk kepada pihak-pihak yang terlibat. Seperti pada pasal 30 Undang-undang pornografi yaitu "Setiap orang yang menyediakan jasa pornografi sebagaimana dimaksud pada pasal 4 ayat (2) dipidana dengan pidana penjara paling singkat 6 (enam) bulan dan paling lama 6 (enam) tahun dan/ atau pidana denda paling sedikit Rp. 250.000.000,- (dua ratus lima puluh juta rupiah) dan paling banyak Rp. 3.000.000.000,- (tiga milyar rupiah)

Pasal di atas berlaku bagi siapa saja yang melakukan melakukan kejahatan pasal 4 ayat (2) huruf d dengan pidana kurungan paling lama 6 tahun dan/ atau denda 3 milyar. Kata "setiap" orang pada pasal tersebut berlaku untuk warga negara Indonesia maupun tidak yang memiliki website. Selain itu, bagi mucikari baik pemilik website ataupun tidak juga dikenakan pasal 35 Undang-undang Pornografi, karena mucikari adalah orang yang menjadikan orang lain (PSK) sebagai objek atau model yang mengandung muatan pornografi. Isi dari pasal tersebut adalah "Setiap orang yang menjadikan orang lain sebagai objek atau model yang mengandung muatan pornografi sebagaimana dimaksud dalam pasal 9 dipidana dengan pidana penjara paling singkat 1 (satu) tahun dan paling lama 12 (dua belas) tahun dan/ atau pidana denda paling sedikit Rp. 500.000.000,- (lima ratus juta rupiah) dan paling banyak Rp. 6.000.000.000,- (enam milyar rupiah) (UU RI No. 35 Tahun 2014 2016).

Hukuman bagi mucikari pada pasal tersebut adalah penjara maksimal 12 tahun dan atau denda paling banyak 6 milyar rupiah. Pihak lain yang tentu juga terkena pidana pada undang-undang ini adalah pemilik server, pasal yang menjeratnya adalah pasal 33 sebagai pihak yang memfasilitasi adanya praktik prostitusi. Pasal tersebut berbunyi "Setiap orang yang mendanai atau memfasilitasi perbuatan sebagaimana dimaksud dalam pasal 7 dipidana 
dengan pidana penjara paling singkat 2 (dua) tahun dan paling lama 15 (lima belas) Tahun dan/ atau pidana denda paling sedikit Rp. 1.000.000.000,- (satu milyar rupiah) dan paling banyak Rp. 7.500.000.000,- (tujuh milyar lima ratus juta rupiah). Sebagai objek dari berlikunya praktik prostitusi, pekerja seks komersial pun ikut dijerat dalam undang-undang ini. Sebagaimana yang terdapat dalam pasal 34 berikut "Setiap orang yang dengan sengaja atau atas persetujuan dirinya menjadi objek atau model yang mengandung muatan pornografi sebagaimana dimaksud dalam Pasal 8 dipidana dengan pidana penjara paling lama 10 (sepuluh) tahun dan/ atau pidana denda paling banyak Rp. 5.000.000.000,- (lima milyar rupiah).

Pasal-pasal di atas merupakan bentuk larangan tertulis yang diberlakukan bagi para pihak yang terlibat dalam praktik prostitusi, baik online maupun secara langsung. Meskipun demikian, makin hari justru semakin meningkat praktiknya di lapangan. Sebagai contoh rangkaian kasus prostitusi yang beredar di Kota Padang, Sumatera Barat. Fenomena ini menjadikan nama baik kota Padang yang religius menjadi ternoda oleh praktik-praktik amoral, sehingga menodai falsafah luhur yang dimiliki masyarakat Minangkabau, Adat Basandi Syarak, Syarak Basandi Kitabullah (ABSSBK). Keadaan ini memberikan keresahan bagi para orang tua dan masyarakat yang tinggal disekitar lokalisasi praktik perbuatan haram ini, rasa cemas pun bermunculan terhadap warga kota Padang yang mayoritas tinggal di tepian pantai. Apabila praktik prostitusi terus beroperasi dikhawatirkan akan mengundang murka Allah SWT berupa gempa dan tsunami seperti yang pernah terjadi pada tahun 2009 lalu.

Maraknya kasus prostitusi di Sumbar menyebabkan kekhawatiran seluruh elemen masyarakat, baik para orang tua, pendidik, ninik mamak, para Ustadz, hingga pemerintah itu sendiri. Syamsi juga mengatakan bahwa sebagian besar PSK melakukan pekerjaan tersebut salah satunya adalah disebabkan oleh faktor ekonomi dan gaya hidup yang glamour (Syamsi 2016). Berdasarkan kekhawatiran tersebut, maka Pemerintah Sumatera Barat mencantumkan undang-undang prostitusi Peraturan Gubernur Sumatera Barat Nomor 56 tahun 2009 tentang Pembentukan Organisasi dan Tata Kerja Unit Pelaksana Teknis Dinas di lingkungan Dinas Sosial Provinsi Sumatera Barat (Sumbar 2009). Adanya Undang-undang pelarangan praktik prostitusi pun menurut penulis belum sepenuhnya berhasil memberantas secara sempurna sehingga memang tidak ada lagi ajang transaksi haram tersebut. Hal ini dibuktikan dari masih adanya tempat-tempat hiburan yang bernuansa mengundang praktik tersebut. Sebagai contoh kafe remang-remang yang berdiri sepanjang Bukit Lampu, dan sejumlah salon yang berada di pasar raya kota Padang masih bermunculan dengan wajah barunya meskipun sudah berulang kali dilakukan penertiban oleh pihak pemerintah maupun organisasi 
masyarakat. Artinya masih perlu adanya tindak lanjut secara berkesinambungan dalam hal mengatasi aktivitas prostitusi ini.

\section{LARANGAN AGAMA}

Agama Islam memandang prostitusi termasuk dalam kategori perbuatan zina, di mana pelaku, perantara, pengguna jasa, maupun pemberi informasi semuanya merupakan perbuatan dosa besar. Sebagaimana tercantum di dalam Q.S. Al-Isra: 32 yang artinya "dan janganlah kamu mendekati zina; Sesungguhnya zina itu adalah suatu perbuatan yang keji dan suatu jalan yang buruk" (Al-Quran dan Terjemahannya 2004). Ayat lain juga Allah mengatakan hukuman yang pantas diterima oleh orang-orang yang melakukan perzinaan, baik itu laki-laki maupun perempuan itu sendiri sebagaimana terdapat di dalam QS. An-Nur: 2-3 yang artinya "Perempuan yang berzina dan laki-laki yang berzina, maka deralah tiap-tiap seorang dari keduanya seratus kali dera, dan janganlah belas kasihan kepada keduanya mencegah kamu untuk (menjalankan) agama Allah, jika kamu beriman kepada Allah, dan hari akhirat, dan hendaklah (pelaksanaan) hukuman mereka disaksikan oleh sekumpulan orang-orang yang beriman. Laki-laki yang berzina tidak mengawini melainkan perempuan yang berzina, atau perempuan yang musyrik; dan perempuan yang berzina tidak dikawini melainkan oleh laki-laki yang berzina atau laki-laki musyrik, dan yang demikian itu diharamkan atas orang-orang yang mukmin".

Ayat di atas jelas sekali Allah SWT melarang praktik perbuatan prostitusi karena bahaya yang ditimbulkannya, sehingga Allah SWT mengatakan bahwa untuk perempuan yang berbuat zina, maka pasangan yang tepat baginya adalah laki-laki pezina juga maupun perempuan yang musyrik. Turunnya Q.S An-Nur: 3 di atas dilatar belakangi oleh adanya sahabat Nabi Muhammad SAW yang ingin menikahi seorang pekerja prostitusi Qurays yang bernama Umi Makhzul, sehingga Allah SWT menurunkan ayat tersebut kepada Nabi Muhammad SAW sebagai bentuk larangan mengawininya. (Mahali 2002). Sedangkan Sayid Sabiq mengatakan maksud pengharaman pada ayat di atas adalah bahwa orang mukmin dilarang untuk menikahi siapapun yang berstatus sebagai pezina ataupun pelaku kemusyrikan karena mereka tak layak untuk dinikahi kecuali oleh mereka yang berstatus sebagai pezina atau musyrik saja (Sabiq 2009). Nabi Muhammad SAW juga mengatakan di dalam haditsnya yang diriwayatkan oleh Abu Hurairah, r.a bahwa Rasulullah SAW bersabda :

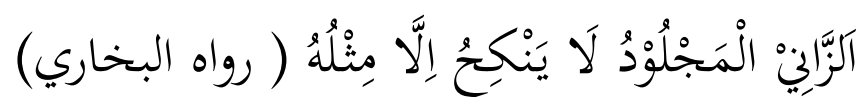

Artinya : 
"Seorang laki-laki pezina yang pernah dihukum dera tidak akan menikah kecuali dengan perempuan yang sepertinya (pezina). (HR. Bukhari) (Sabiq 2009).

Hadits di atas merupakan penguat larangan berbuat zina, sehingga Nabi Muhammad SAW sendiri memberikan pilihan pasangan yang sesuai yaitu sama-sama pezina. Bahkan lebih tegas lagi larangan beliau terhadap perbuatan prostitusi ini dengan memberikan hukuman rajam bagi para pezina yang telah berkeluarga. Hal ini disebabkan karena besarnya dampak yang membahayakan baik terhadap kesehatan, keturunan, maupun hubungan lingkungannya.

Negara Indonesia telah mengeluarkan Undang-Undang terhadap larangan prostitusi, baik bagi pelaku maupun mucikari/ perantara. Namun di lapangan, larangan tersebut kurang diperhatikan, bahkan semakin hari semakin banyak jumlah orang yang melanggar larangan tersebut. Salah satu contoh khususnya di kota Padang sendiri dalam razia pekat yang dilakukan oleh Satuan Polisi Pamong Praja (Satpol PP) dan pihak kepolisian di seluruh wilayah Sumatera Barat sepanjang tahun 2016 tercatat sebanyak 108 PSK yang kemudian di karantinakan untuk direhabilitasi di panti sosial pekerja seks komersial. Selain itu, di wilayah Bukit Lampu Bungus juga mulai terlihat kembali aktivitas warung remang-remang di sepanjang jalan di lereng-lereng bukit, padahal sebelumnya telah diadakan razia dan pemberantasan total di sepanjang jalan Bukit Lampu tersebut (El-Faruqi 2017).

\section{UPAYA PREVENTIF}

Pencegahan terjadinya praktek prostitusi baik online maupun langsung lebih baik daripada merehabilitasi. Proses pencegahan membutuhkan tahapantahapan tepat yang terukur dan teruji ${ }^{5}$. Dalam kehidupan nyata, persoalan prostitusi tidak terlepas dari dua faktor, yaitu faktor internal dan faktor eksternal. Salah satu bentuk faktor internal adalah adanya dorongan jiwa untuk melakukan sesuatu karena suatu keterpaksaan emosi, sehingga dalam kondisi tertekan dapat melakukan hal-hal yang melampaui batas kewajaran6. Faktor internal dapat ditimbulkan dari dorongan luar maupun diri sendiri. Sedangkan faktor eksternal merupakan faktor penyebab yang berasal dari luar diri baik lingkungan keluarga, lingkungan pendidikan, lingkungan bekerja, lingkungan pergaulan, maupun benda di sekitar yang berada di luar tubuh lainnya. Pada penelitian ini langkah preventif yang dilakukan adalah;

\footnotetext{
${ }^{5}$ Hartini (Setjen DPR RI) Retnaningsih, 'Dampak Sosial Penutupan Lokalisasi Dolly', Info Singkat Kesejahteraan Sosial, 2014.

${ }^{6}$ Kata kunci, Interaksi Sosial, and Pekerja Seks Komersial, 'Interaksi Sosial Pekerja Seks Komersial Lokalisasi Bandang Raya Dengan Masyarakat Kelurahan Mugirejo, Kota Samarinda', EJournal Ilmu Sosiatri, 2014.
} 


\section{Pembentukan wirid remaja}

Wirid remaja merupakan suatu kegiatan ibadah yang di laksanakan di masjid atau mushalla. Pelaksananya adalah para remaja yang berdomisili di sekitar mushalla atau masjid dan motori oleh pengurus masjid/mushalla, tokoh masyarakat hingga organisasi kepemudaan. Wirid remaja dibentuk dari organisasi remaja masjid/mushalla yang disebut dengan IRMA (Ikatan Remaja Masjid). Ikatan ini memiliki struktur anggaran dasar rumah tangga sendiri dan membentuk kepengurusan yang berperan sebagai motor penggerak program kegiatan IRMA itu sendiri.

Remaja masjid adalah organisasi yang menghimpun remaja muslim yang aktif datang dan beribadah shalat berjama'ah di masjid. Karena keterikatannya dengan masjid, maka peran utamanya tidak lain adalah memakmurkan masjid. Ini berarti, kegiatan yang berorientasi pada masjid selalu menjadi program utama. Di dalam melaksanakan peranannya, remaja masjid meletakkan prioritas pada kegiatan-kegiatan peningkatan keislaman, keilmuan dan keterampilan anggotanya ${ }^{7}$. Menurut C.S. T. Kansil Dalam Bukunya berjudul " Pancasila dan Undang-Undang Dasar 1945 ", mengatakan : Remaja masjid merupakan suatu wadah bagi remaja Islam yang cukup efektif dan efisien untuk melaksanakan aktivitas pendidikan Islam. Remaja-remaja berkepribadian muslim ini dapat melanjutkan harapan bangsa menuju cita-cita yang luhur dan berbudi pekerti yang baik sesuai dengan Pancasila dan Undang-Undang Dasar tahun 1945 yaitu "untuk mensejahterakan kesejahteraan umum, mencerdaskan kehidupan bangsa dan ikut serta dalam melaksanakan ketertiban dunia". ${ }^{8}$

Kegiatan wirid remaja sudah mendarah daging di Kota Padang, bahkan hampir di setiap kelurahan melakukan kegiatan ini. Salah satu motivasi dan faktor penggeraknya adalah adanya peraturan Pemko kota Padang yang mengharuskan peserta didik tingkat SMP dan SMA sederajat memiliki sertifikat aktif mengikuti kegiatan wirid remaja di akhir semester pertama mereka. Hal ini menjadi cambuk bagi para remaja untuk turut serta mengikuti kegiatan tersebut karena menambah poin penilaian di dalam buku raportnya. Bahkan di salah satu sekolah menjadikan sertifikat wirid remaja sebagai salah satu persyaratan naik kelas yang diserahkan setiap akhir semester. Kegiatan wirid remaja menjadi kegiatan wajib bagi

${ }^{7}$ MNoupal xx and Sri Aliyah xxx Fakultas Ushuluddin dan Pemikiran Islam UIN Raden Fatah Palembang, 'PERAN SOSIAL KEAGAMAAN REMAJA MASJID DI KELURAHAN PIPA REJA KECAMATAN KEMUNING PALEMBANG', Peran Sosial Keagamaan Remaja Masjid Di Kelurahan Pipa Reja... JSA Vol, 2017.

8 Niken Puspitasari and others, 'Pendampingan Penguasaan Bahasa Inggris Dan Penguatan Akidah Pada Remaja Masjid Sebagai Pemandu Wisata Desa Wisata Towil, Kulonprogo, Dalam Menghadapi Masyarakat Ekonomi Asean (MEA)', Jurnal Bakti Saintek: Jurnal Pengabdian Masyarakat Bidang Sains Dan Teknologi, 2017. 
para remaja yang bersekolah di kota Padang. Dukungan Pemko terhadap kegiatan keagamaan dapat dijadikan contoh bagi Pemko daerah lain, hal ini dibuktikan dari setiap hari-hari besar Islam yang terus melibatkan para remaja untuk meramaikan masjid. Sebagai contoh kegiatan pesantren Ramadhan yang di laksanakan selama 15 hari di bulan Ramadhan, kegiatan pawai 1 Muharram, kegiatan pekan maulid, kegiatan didikan subuh, khatam al-Qur'an dan banyak kegiatan keagamaan lain yang di support.

Saat ini kota Solok juga tengah mencanangkan kegiatan-kegiatan keagamaan dengan gencar. Kota Solok yang merupakan bagian dari wilayah propinsi Sumatera Barat merupakan daerah kategori beragama yang kuat, hal ini terlihat dari falsafah yang dimiliki oleh masyarakat minang itu sendiri yaitu Adat Basandi Syarak, Syarak Basandi Kitabullah $(\text { ABSSBK })^{9}$. Sebagai bukti bahwa semakin banyak dan berkembangnya pondok pesantren di Kota Solok. Hal ini menjadikan daerah ini bernuansa agamis, sehingga jika ada kemaksiatan yang di umbar begitu saja dan tidak segera di tindak lanjuti maka dapat menciderai falsafah yang mulia ini ${ }^{10}$. Sebagai bentuk upaya melestarikan falsafah yang sudah terpelihara dan terjaga ini masyarakat di Sumbar khususnya suku minang. Maka, para tokoh agama di dukung oleh Pemko membuat suatu keharusan bagi peserta didik tingkat SMP dan SMA sederajat mengikuti kegiatan wirid remaja di sekitar tempat tinggal mereka. Wirid remaja di laksanakan di masjid maupun mushalla terdekat. Kegiatan ini selaras dengan slogan para orang tua masyarakat minang yaitu kembali ke surau ${ }^{11}$.

Tujuan dari wirid remaja ini adalah membentuk karakter siswa yang berakhlak mulia, menanamkan nilai-nilai aqidah dan wawasan keislaman yang kuat. Pelaksanaan kegiatan dilakukan seminggu sekali dengan di bimbing oleh para mahasiswa yang juga berdomisili di sekitar masjid atau mushalla. Program seperti tahfidz, tanya jawab seputar fiqih, serta diskusi perkembangan remaja merupakan rutinitas kegiatan setiap minggunya. Ditambah dengan tausiyah dari Ustad “jaman now” yang dapat melihat masalah-masalah para remaja. Salah satu masalah yang urgen adalah pengaruh pergaulan melalui media sosial yang tidak terbendung lagi. Para remaja dalam kesendiriannya di kamar dapat berkomunikasi dengan sejumlah pengguna media lain, baik itu teman maupun orang lain yang belum dikenalnya. Hal ini yang menjadi perhatian serius para pendidik, yaitu menanamkan benteng keimanan yang kuat sehingga para

9 Ahmad Kosasih, 'Upaya Penerapan Nilai-Nilai Adat Dan Syarak Dalam Penyelenggaraan Pemerintahan Nagari', Humanus, 2013.

10 Kosasih.

11 Darwianis, 'Tindak Lanjut Kebijakan Kembali Ke Nagari Dan Ke Surau Serta Dampaknya Terhadap Kehidupan Sosial Adat Keagamaan Masyarakat', Jurnal PPKn \& Hukum, 2017. 
remaja tidak terjermus ke dalam degradasi moral. Melalui kegiatan wirid remaja yang dilaksanakan seminggu sekali setidaknya meminimalisir tindakan yang bersifat amoral seperti tindakan asusila dan praktek prostitusi.

\section{Pengajian rutin mingguan}

Pengajian yang dilaksankan secara rutinitas sekali dalam seminggu dapat meminimalisir terjadinya praktek prostitusi. Hampir sama dengan kegiatan wirid remaja, pengajian rutin ini lebih khususnya dilakukan oleh para ibu rumah tangga. Jika wirid remaja jamaahnya adalah para remaja, sedangkan pengajian adalah para ibu. Kegiatan ini telah berjalan dari tahun ke tahun dan telah membudaya sendiri, sehingga jika tidak dilaksanakan dalam minggu tersebut menjadi bagian hidup yang kurang. Melalui kegiatan ini pembinaan aqidah dapat terjaga, wawasan pengetahuan Islam terus bertambah dan bermuamalah dengan masyarakat berjalan dengan syariat ${ }^{12}$. Pengajian rutin ini juga tidak hanya di ikuti oleh ibu-ibu saja, namun juga dari jamaah laki-laki. Untuk pengajian sore pelaksanaannya diiringi dengan arisan, sehingga jamaah pengajian hanya terdiri dari kaum ibu saja. Sementara pengajian yang dilaksanakan setelah maghrib menjelang isya diikuti oleh jamaah laki-laki dan perempuan. Pengajian rutin di motori oleh pengurus masjid, melalui semangat gotong royong bahu membahu menggalang dana untuk cost penceramah, sehingga setiap minggu mendatangkan penceramah yang baru.

Melalui adanya kegiatan pengajian rutin ini, masyarakat akan memiliki keimanan yang kuat sehingga mengetahui sedikit banyak tentang batasan-batasan syariat Islam. Melalui kegiatan yang disyiarkan menggunakan pengeras suara dapat meminimalisir tindak perbuatan prostitusi. Tempat-tempat lokalisasi yang berada disekitar pengajian akan merasa resah dan secara perlahan akan ditutup. Begitu juga dengan pelaku itu sendiri, saat mendengar tausiyah Ustad di Masjid/mushalla mereka akan merasa bersalah dan mengurangi niat untuk melakukan perbuatan maksiat $^{13}$.

\section{Pengajuan dana usaha melalui dana hibah mitra binaan ekonomi ummat}

12 Husnul Fahimah Ilyas, 'Menyoal Peran Dan Fungsi Masjid Pemerintah Studi Atas Masjid Agung Syuhada Polewali Mandar Makassar', International Journal Ihya' 'Ulum Al-Din, 2017 <https://doi.org/10.21580/ihya.16.2.1655>.

13 Mohd Azrin Johari, 'PENGAJIAN HADIS DI MASJID DAN SURAU: ANALISIS TERHADAP TAHAP KEFAHAMAN HADIS (The Learning of Hadis at Mosques and Madrasahs: An Analysis on the Level of Understanding of Hadis)', Jurnal Hadhari, 2016. 
Salah satu penyebab terjadinya praktek prostitusi, baik online maupun langsung adalah karena faktor ekonomi ${ }^{14}$. Kebutuhan ekonomi adalah salah satu faktor terbesar dari sekian faktor penyebab lainnya. Hal ini berdampak terhadap capaian penghasilan seseorang. Faktor ekonomi juga menjadi salah satu penyebab kemiskinan. Kemiskinan adalah sebuah masalah yang sangat kompleks dalam kehidupan manusia. Kemiskinan yang terjadi dalam kehidupan manusia tidak terjadi begitu saja, kemiskinan disebabkan baik faktor internal maupun eksternal. Faktor internal meliputi individu itu sendiri, dan faktor eksternal misalnya keluarga, lingkungan, pemerintahan, keadaan perekonomian secara umum, dan banyak hal lainnya ${ }^{15}$.

Sebagai salah satu contoh bahwa kemiskinan adalah salah satu penyebab terjadinya prostitusi yaitu hasil wawancara penulis terhadap salah seorang eks PSK di Panti Sosial Karya Wanita (PSKW) Andam Dewi Solok. Ade Elfira, seorang eks PSK mengatakan bahwa dirinya terjun ke dunia prostitusi karena kebutuhan ekonomi. Di samping itu, beberapa eks PSK yang lain juga membenarkan hal tersebut. Di antara mereka ada yang sudah berpisah dengan suami, ada yang tidak memiliki tempat tinggal, hingga ada yang malu menjalani kehidupan akibat kondisi perekonomian yang memprihatinkan. Kondisi tersebut merupakan dampak dari faktor ekonomi, di samping banyak faktor lain yang mempengaruhi.

Dana bantuan usaha untuk masyarakat menengah kecil saat ini mudah di dapatkan ${ }^{16}$. Pengusul dana bantuan dapat mendatangi lembaga atau badan yang meminjamkan dana usaha. Saat ini, bentuk-bentuk lembaga yang memberikan bantuan usaha seperti Lazis, Baznas, BMT, UMKM Syariah, hingga produk-produk pinjaman syari'ah lainnya ${ }^{17}$. Pengusul dana bantuan hanya memenuhi syarat yang ditetapkan dan setelah dinyatakan layak oleh pihak pemberi bantuan dana, maka pengusul memperoleh dana usaha sekaligus bimbingan usaha sampai mandiri. Lembaga pemberi dana bantuan usaha biasanya memprioritaskan calon penerima yang betul-betul layak dan pantas untuk mendapat pendampingan usaha dengan melihat keadaan ekonomi pengusul ${ }^{18}$. Selain dari dana hibah lepas, juga ada dana bantuan usaha yang bersifat pinjaman,

14 Lutfi Irwansyah, 'Kemiskinan , Keluarga Dan Prostitusi Pada Remaja', Psychology and Humanity, 2016.

15 Rini Fathonah, 'Analisis Terhadap Faktor Penyebab Prostitusi Pada Anak', Jurnal Poenale, 2016.

16 Prehantoro Prehantoro, 'FUNGSI SOSIAL BANK SYARIAH', Perspektif, 2010.

17 Ilanugrahani, 'Amil Zakat Di Era Modern', ZIS, 2014.

18 Maltuf Fitri, 'Pengelolaan Zakat Produktif Sebagai Instrumen Peningkatan Kesejahteraan Umat', Economica: Jurnal Ekonomi Islam, 2017 <https://doi.org/10.21580/economica.2017.8.1.1830>. 
seperti BMT Syariah, UMKM Syariah, koperasi 212 dan lembaga lainnya lainnya ${ }^{19}$.

Semua bentuk lembaga penyalur dana bantuan usaha di atas merupakan salah satu alternatif solusi yang berfungsi mengurangi bentuk kemiskinan karena keterbatasan ekonomi masyarakat. Masyarakat dapat merasakan kehadiran lembaga yang peduli dengan kehidupan mereka, lembaga yang memang hadir untuk membantu masyarakat yang butuh modal usaha. Lembaga tersebut juga menggunakan sistem syari'ah yang mengutamakan sistem bagi hasil secara Islami. Meskipun banyak lembagalembaga penyalur dana bantuan, namun lebih baik jika lembaga tersebut berbasis syariah, agar dikemudian hari usaha yang dibangun menjadi berkah ${ }^{20}$.

Langkah di atas merupakan upaya dalam hal mengatasi praktek prostitusi melalui upaya preventif, yaitu mencegah sebelum terjerumus ke dalam lembah kemaksiatan. Namun, bagi para pelaku yang sudah terjaring terlibat dalam transaksi praktek ini pemerintah juga telah memikirkan solusinya. Seperti yang dilakukan oleh PSKW Andam Dewi Solok sebagai lembaga Rehabilitasi untuk para PSK. Kebanyakan PSK yang mengikuti program rehabilitasi di tempat tersebut berasal dari hasil razia Sat Pol PP, kemudian di kirim ke Panti Sosial ini untuk dilakukan upaya rehabilitasi. Dalam kegiatan rehabilitasi pemerintah Kota Solok di dukung oleh Gubernur Sumbar agar membuat program-program rehabilitasi yang diperlukan oleh para eks PSK dan dapat membentuk moral yang baik. Program-program tersebut terdiri dari program keagamaan, program keterampilan dan kerajinan tangan, serta program pendampingan jangka panjang.

\section{Keagamaan}

Program keagamaan merupakan program kegiatan yang menyangkut dengan agama, baik secara teori maupun praktek. Program ini lebih fokus kepada penanaman aqidah, penanaman pondasi keimanan. Tahap awal yang dilakukan di Panti Sosial ini adalah memberikan kesadaran secara totalitas terhadap perbuatan-perbuatan yang telah dilakukannya. Instruktur dan pemateri berperan sebagai konselor sekaligus fasilitator dalam memberikan penguatan aqidah, pelaksananya adalah Eks PSK itu sendiri. langkah awal ini bertujuan untuk membangun sugesti berupa dorongan jiwa untuk melakukan tugas-tugas baik sesuai dengan printah Allah dan Rasul-Nya. Sehingga, jika aqidahnya sudah kokoh

19 Ahmad Guspul and others, 'Kualitas Pelayanan, Kepuasan Dan Kepercayaan Nasabah Pada Koperasi Jasa Keuangan Syariah Di Wonosobo', Jurnal PPKM III, 2014.

20 Eva Roviana, 'Margin Dan Kualitas Pelayanan Terhadap Keuangan Syariah (Studi Kasus BMT Amal Mulia ) Skripsi', Fakultas Ekonomi Universitas Syiah Kuala Banda Aceh, 2015. 
program-program yang dicanangkan di Panti Sosial tersebut akan dilakukan karena Ridha Allah SWT semata ${ }^{21 .}$

Program keagamaan terdiri dari taklim, praktek ibadah, serta muhasabah. Pertama yaitu Taklim. Taklim berarti proses pembelajaran melalui tatap muka dan diskusi ${ }^{22}$. Menurut salah seorang Instruktur yang membimbing proses taklim, mengatakan bahwa taklim merupakan proses pemberian pengetahuan, pemahaman, pengertian, dan tanggung jawab sehingga manusia menjadi suci atau bersih dari segala kotoran sehingga siap menerima hikmah dan mampu mempelajari hal-hal yang bermanfaat bagi dirinya. Taklim ini bertujuan untuk membekali para eks PSK terhadap prinsip-prinsip agama Islam (Riski 2017). Taklim dilakukan seperti proses belajar mengajar di pesantren, eks PSK diberikan materi pelajaran oleh para instruktur sesuai jadwal pelajaran yang ditetapkan. Waktu pelaksanaan taklim setiap hari senin hingga kamis mulai pukul $08.00 \mathrm{~s} / \mathrm{d}$ 09.30. Selama proses rehabilitasi, peserta harus mengikuti kegiatan ini selama 6 bulan lamanya. Hasil dari penelitian ini terlihat bahwa program taklim memberikan dampak positif, terutama pada penguatan aqidah yang menjadi benteng pertahanan diri seseorang dalam menentukan mana yang baik dan mana yang buruk. Melalui taklim peserta rehabilitasi dapat bertanya dan saling berbagi pengalaman yang telah di lewati sehingga para pemateri dapat memberikan alternatif contoh sikap yang harus dilakukan oleh peserta ketika dihadapkan dengan persoalan tersebut. Indikator keberhasilan taklim adalah capaian hasil akhir dari tim penilai yang terus mengawasi aktivitas eks PSK selama 6 bulan, dan dituangkan dalam raport. Jika nilai nya mencapai KKM (kriteria ketuntasan minimal) maka peserta rehabilitasi diperbolehkan pulang. Namun, jika belum mencapai batas nilai minimal, akan ditambah waktu pembinaannya.

Kedua, praktek ibadah. Setiap peserta rehabilitasi dibekali dengan teori dan praktek ibadah yang benar. Pendampingan praktek ibadah ini dilakukan setiap hari oleh instruktur wanita, sehingga ketika ada permasalahan dapat segera ditindak lanjuti. Indikator capaian yang diharapkan dari program ini adalah pembiasaan secara sadar. Jika peserta rehabilitasi sudah terbiasa dan pandai melakukan sendiri maka program ini dinyatakan berhasil. Namun, capaian yang diharapkan sesungguhnya adalah pengaplikasian dalam kehidupan sehari-hari mereka saat berada di luar lingkungan rehabilitasi. Pembelajaran pertama yang diberikan oleh instruktur PSKW Andam Dewi dalam menanamkan nilai-nilai pendidikan

21 Othman Zuraidah and Aizan Ali @ Mat Zin, 'Pendidikan Integratif Dalam Islam: Kesepaduan Iman, Ilmu Dan Amal', Al Muqaddimah, 2014 <https://doi.org/10.1017/CB09781107415324.004>.

${ }^{22}$ Ahmad Sarbini, 'Internalisasi Nilai Keislaman Melalui Majelis Taklim', Jurnal Ilmu Dakwah, $2010<$ https://doi.org/10.15575/jid.v5i16.355>. 
ibadah terhadap eks PSK adalah di awali dengan thaharah. Thaharah merupakan pelajaran awal yang harus dikuasai oleh eks PSK. Thaharah merupakan suatu syarat sahnya shalat, maka ini wajib diketahui bagi setiap muslim laki-laki maupun perempuan, baligh dan berakal yang tidak bisa diwakilkan kepada orang lain. Berdasarkan pengamatan yang penulis lakukan tersebut, penulis melihat instruktur mengajarkan bagaimana cara thaharah yang benar kepada eks PSK. Eks PSK diharuskan menguasai tatacara thaharah mulai dari pemberian materi dalam bentuk teori, dan pembimbingan dalam bentuk praktek berwudhu langsung. Seperti yang disampaikan oleh Ustadz Sarimun, selaku pembimbing bidang ibadah. Beliau mengatakan hendaknya eks PSK dapat membiasakannya dalam keseharian, agar melaksanakan thaharah tidak dirasakan sebagai suatu yang berat, dan menjadi bagian keseharian mereka (Sarimun 2017).

Bentuk praktek ibadah yang diajarkan mulai dari pengenalan thaharah baik teori maupun praktek, membaca al-Qur'an, shalat wajib dan shalat sunnah, puasa serta hafalan surat-surat pilihan. Beberapa program di atas secara keseluruhan $75 \%$ tercapai. Hal ini dilihat dari pembiasaan aktivitas ibadah yang dilakukan meskipun belum mencapai target maksimal. Kendala yang dihadapi adalah jumlah tenaga pendamping yang perlu di tambah dan pemberian bekal pengetahuan yang mumpuni. Namun, secara totalitas kegiatan ini sudah dilakukan dan berjalan dengan lancar.

Ketiga adalah muhasabah. Muhasabah berarti menghitung, yaitu menghitung berapa banyak jumlah kebaikan dan keburukan yang pernah dilakukan ${ }^{23}$. Apakah jumlah kebaikan yang lebih banyak ataukah justru sebaliknya. Namun hal ini tentu tidak bisa dilakukan jika harus menghitung dan mencatatnya, akan tetapi masing-masing kita dapat merasakannya sendiri. Program muhasabah tidak jauh berbeda dengan penguatan akidah, program ini lebih terfokus kepada pengembalian tindakan sadar seseorang secara totalitas ${ }^{24}$. Program ini menjadi program awal yang dilakukan di Panti Sosial Karya Wanita Andam Dewi Solok sebelum melakukan program-program selanjutnya. Menurut Syahbana, selaku pimpinan PSKW Andam Dewi menjelaskan program ini adalah program instalasi. Di mana manusia pun dapat di instal ulang layaknya komputer agar bersih dari virus dan program yang dioperasionalkan kembali berjalan normal. Muhasabah dilakukan pada malam hari selepas shalat Isya dalam jangka waktu sekali dalam sebulan. Meskipun kegiatan intinya adalah sekali

${ }^{23}$ Marina Munira, Abdul Mutalib, and Noratthiah Nordin, 'Model Taubat Al-Ghazali (M-TaG)', 'Ulum Islamiyyah Journal, 2014 < https://doi.org/10.12816/0012627>.

24 Muhammad Shohib, 'Taubat Sebagai Metode Dasar Psikoterapi Islam', Seminar Psikologi \& Kemanusiaan, 2009. 
dalam sebulan, akan tetapi setiap hari pun diberikan jadwal muhasabah kecil menjelang tidur di malam hari, baik berupa kisah-kisah inspiratif maupun pengalaman pahit eks PSK yang menjadi pemicu untuk berhijrah. Kegiatan ini menjadi rutinitas harian, sehingga proses instal terus dilaksanakan agar memperkuat keimanan demi mencapai istiqomah.

\section{Keterampilan dan kerajinan tangan}

Upaya selanjutnya adalah pemberian keterampilan kepada para eks PSK yang mengikuti program rehabilitasi. Bekal keterampilan yang diberikan berupa keterampilan menjahit, berkebun, mengukir, menyulam, hingga membuat aneka makanan. Pelaksanaan pembekalan dilakukan berdasarkan jadwal yang telah ditentukan, peserta diberikan alat dan fasilitas yang sudah tersedia di dalam ruang keterampilan. Peserta juga dapat memilih mana keterampilan yang lebih disukainya sehingga menjadi lebih terampil dan bisa dijadikan skill saat keluar dari lingkungan rehabilitasi. Beberapa hasil kerajinan tangan yang dihasilkan seperti keset, tas kain, taplak meja dan hasil jahitan lainnya. Melalui Program keterampilan dan kerajinan ini nantinya peserta akan diberikan dana bantuan usaha yang diberikan oleh Donatur, Dinas Sosial, LSM dan Panti Sosial itu sendiri yang telah menjalin kerjasama dengan UMKM setempat. Salah seorang eks PSK, Mira mengatakan bahwa setelah keluar dari panti rehabilitasi ini dirinya akan meneruskan hasil kerajinannya berupa tas dompet, berbeda dengan Elsa yang ingin bertanam sayuran.

\section{Pendampingan jangka panjang}

Setelah selesai mengikuti proses rehabilitasi selama 6 bulan para eks PSK dianjurkan untuk melaporkan aktivitas kegiatannya secara continue dan berkala. Program ini bertujuan agar mereka tidak terjun kembali ke dalam dunia prostitusi. Manakala ditemukan penyimpangan di lapangan, pihak Panti Sosial dapat melakukan teguran bahkan membawa kembali ke panti rehabilitasi. PSKW saat ini telah bekerja sama dengan pihak kepolisian, Sat Pol PP, dinas kesehatan, serta LSM di seluruh wilayah Sumatera Barat. Maka, jika dikemudian hari terdapat "alumni" PSKW yang terjaring razia pekat, dapat segera ditindak lanjuti kembali.

Pendampingan yang dilakukan berupa komunikasi via telepon, maupun kunjungan rumah. Bagi eks PSK yang berdomisil di sekitar Panti Sosial akan dikunjungi secara intens layaknya family sendiri. Namun, bagi yang berdomisili di luar kota dapat melibatkan pihak-pihak dari dinas sosial maupun dari pihak LSM. Pendampingan jangka panjang ini secara tidak langsung membangun hubungan keluarga antara eks PSK dengan pihak Panti Sosial. Setelah mereka selesai mengikuti proses rehabilitasi, mereka diperbolehkan berkunjung kapan saja. Mereka diajarkan bahwa tempat rehabilitasi layaknya rumah bagi mereka sendiri. Bahkan Ade 
Efdira , salah satu dari eks PSK yang mengikuti rehabilitasi salah satunya ada yang bekerja sebagai pendamping dan instruktur di tempat tersebut. hal ini membuktikan bahwa program pendampingan ini menciptakan hubungan emosional dan berdampak postitif demi keberhasilan yang maksimal. Saat ini Ade menjabat sebagai bendahara di PSKW Andam Dewi Solok.

\section{PENUTUP}

Berdasarkan penelitian di atas, penulis menyimpulkan bahwa rehabilitasi eks PSK di Panti Sosial Karya Wanita (PSKW) Andam Dewi Solok yang beralamat di desa Sukarami Jl. Solok-Padang KM. 40 dapat dilakukan dengan cara melakukan upaya preventif dan upaya rehabilitatif. Upaya preventif merupakan upaya pencegahan yang dilakukan melalui kegiatan pembentukan wirid remaja dan pengajian rutin mingguan, serta pengajuan dana bantuan usaha melalui lembaga penyalur dana hibah. Sedangkan upaya rehabilitatif meliputi program keagamaan, keterampilan dan kerajinan tangan serta pendampingan jangka panjang. Proses rehabilitasi dilakukan selama 6 bulan dengan tenaga pendamping dan instruktur berjumlah 12 orang. Secara totalitas program yang dilakukan sudah berjalan dengan lancar meskipun belum mencapai hasil maksimal. Adapun kendala yang dihadapi adalah kurangnya tenaga pendamping dan instruktur. Untuk mengatasinya Pihak Panti Sosial telah mengajukan permohonan kepada Dinas Sosial untuk mengirim bantuan tenaga, baik melalui perekrutan CPNS maupun tenaga kontrak. Kajian ilmiah ini tidak terlepas dari kekurangan, maka dari itu diharapkan kepada pembaca agar dapat memberikan masukan yang bersifat konstruktif.

\section{DAFTAR PUSTAKA}

Darwianis, 'Tindak Lanjut Kebijakan Kembali Ke Nagari Dan Ke Surau Serta Dampaknya Terhadap Kehidupan Sosial Adat Keagamaan Masyarakat', Jurnal PPKn \& Hukum, 2017

Depdikbud. (1984). Kamus Besar Bahasa Indonesia. Jakarta: PN.Balai Pustaka.El-Faruqi, A. (2017). Kasus Prostitusi di Sumbar. Padang: Kompas.

EVA ROVIANA, 'MARGIN DAN KUALITAS PELAYANAN TERHADAP KEUANGAN SYARIAH ( Studi Kasus BMT AMAL MULIA ) SKRIPSI', Fakultas Ekonomi Universitas Syiah Kuala Banda Aceh, 2015

Fahimah Ilyas, Husnul, 'Menyoal Peran Dan Fungsi Masjid Pemerintah Studi Atas Masjid Agung Syuhada Polewali Mandar Makassar', International $\begin{array}{llll}\text { Journal Ihya' 'Ulum } & 2017\end{array}$ <https://doi.org/10.21580/ihya.16.2.1655>

Fathonah, Rini, 'Analisis Terhadap Faktor Penyebab Prostitusi Pada Anak', 
Jurnal Poenale, 2016

Fitri, Maltuf, 'Pengelolaan Zakat Produktif Sebagai Instrumen Peningkatan Kesejahteraan Umat', Economica: Jurnal Ekonomi Islam, 2017 <https://doi.org/10.21580/economica.2017.8.1.1830>

Hermansyah, A. (2016). Menyorot Prostitusi Mobil Sewaan di Kota Padang. Padang: Sumbarsatu Padang.

Gunawan Prakoso*, Ani Purwanti, Dyah Wijaningsih, 'KEBIJAKAN PEMERINTAH DAERAH DALAM MENANGGULANGI PROSTITUSI DI KABUPATEN BELITUNG PROVINSI BANGKA BELITUNG', Diponegoro Law Journal, 2016

Guspul, Ahmad, Awaludin Ahmad, Penelitian Ini Berjudul, Kualitas Pelayanan, Kepuasan Dan, Kepercayaan Nasabah, and others, 'KUALITAS PELAYANAN, KEPUASAN DAN KEPERCAYAAN NASABAH PADA KOPERASI JASA KEUANGAN SYARIAH DI WONOSOBO', Jurnal PPKM III, 2014

Iis Susanti, Pambudi Handoyo, 'Perilaku Menyimpang Dikalangan Remaja Pada Masyarakat Karangmojo Plandaan Jombang', Paradigma, 2015

Ilanugrahani, 'Amil Zakat Di Era Modern', ZIS, 2014

Irwansyah, Lutfi, 'Kemiskinan , Keluarga Dan Prostitusi Pada Remaja', Psychology and Humanity, 2016

Johari, Mohd Azrin, 'PENGAJIAN HADIS DI MASJID DAN SURAU: ANALISIS TERHADAP TAHAP KEFAHAMAN HADIS (The Learning of Hadis at Mosques and Madrasahs: An Analysis on the Level of Understanding of Hadis)', Jurnal Hadhari, 2016

Kartono, K. (1997). Patologi Sosial. Jakarta: PT. Raja Grafindo Persada.

Kosasih, Ahmad, 'UPAYA PENERAPAN NILAI-NILAI ADAT DAN SYARAK DALAM PENYELENGGARAAN PEMERINTAHAN NAGARI', Humanus, 2013

kunci, Kata, Interaksi Sosial, and Pekerja Seks Komersial, 'Interaksi Sosial Pekerja Seks Komersial Lokalisasi Bandang Raya Dengan Masyarakat Kelurahan Mugirejo, Kota Samarinda', EJournal Ilmu Sosiatri, 2014

Mahali, M. (2002). Asbabun Nuzul. Jakarta: PT. Raja Grafindo Persada.

Mahfudz, S. (1994). Nuansa Fiqh Sosial. Yogyakarta: LKis.

Muhammad Shohib, 'Taubat Sebagai Metode Dasar Psikoterapi Islam', Seminar Psikologi \& Kemanusiaan, 2009

Munira, Marina, Abdul Mutalib, and Noratthiah Nordin, 'Model Taubat AlGhazali (M-TaG)', 'Ulum Islamiyyah Journal, 2014 <https://doi.org/10.12816/0012627>

Prehantoro, Prehantoro, 'FUNGSI SOSIAL BANK SYARIAH', Perspektif, 2010

Puspitasari, Niken, Fatma Dian Pratiwi, Siantari Rihartono, Lukman Nusa, Diah Ajeng Purwani, and Rika Lusri Virga, 'Pendampingan Penguasaan Bahasa 
Inggris Dan Penguatan Akidah Pada Remaja Masjid Sebagai Pemandu Wisata Desa Wisata Towil, Kulonprogo, Dalam Menghadapi Masyarakat Ekonomi Asean (MEA)', Jurnal Bakti Saintek: Jurnal Pengabdian Masyarakat Bidang Sains Dan Teknologi, 2017

P.Masland, R. (1987). Apa yang ingin diketahui Remaja tentang Seks. Jakarta: Bumi Aksara.

Retnaningsih, Hartini (Setjen DPR RI), 'Dampak Sosial Penutupan Lokalisasi Dolly', Info Singkat Kesejahteraan Sosial, 2014

Sabiq, M. S. (2009). Fiqh Sunnah. Jakarta: PT.Pena Pundi Aksara.

Saifuddin, Ahmad, 'Abnormalitas Perilaku Pada Anak Dan Remaja, Sudah Sebegitu Parahnya??', Proceeding Seminar Nasional 'Selamatkan Generasi Bangsa Dengan Membentuk Karakter Berbasis Kearifan Lokal", 2015

Sarimun. (2017, November). Wawancara Langsung tentang Aktivitas Ibadah Eks PSK.

Sumbar, P. G. (2009). UU Pergub Sumbar No. 56. Padang.

Syahbana. (2017, November). Wawancara Kepala UPTD Panti Sosial Karya Wanita (PSKW) Andam Dewi.Sarbini, Ahmad, 'Internalisasi Nilai Keislaman Melalui Majelis Taklim', Jurnal Ilmu Dakwah, 2010 <https://doi.org/10.15575/jid.v5i16.355>

Syamsi, A. (2016). Polisi Bongkar Prostitusi ABG di Padang. Padang: Tempo.

Truong, T. D. (1992). Pariwisata dan Pelacuran di Asia Tenggara. Jakarta: LP3ES.xx, MNoupal, and Sri Aliyah xxx Fakultas Ushuluddin dan Pemikiran Islam UIN Raden Fatah Palembang, 'PERAN SOSIAL KEAGAMAAN REMAJA MASJID DI KELURAHAN PIPA REJA KECAMATAN KEMUNING PALEMBANG', Peran Sosial Keagamaan Remaja Masjid Di Kelurahan Pipa Reja... JSA Vol, 2017

Yanti, Febri, 'DINAMIKA KECENDERUNGAN GAYA HIDUP HEDONIS DAN PERILAKU SEKS BEBAS PADA REMAJA PUTRI', Jurnal Ilmiah Mahasiswa Bimbingan \& Konseling, 2016

Zuraidah, Othman, and Aizan Ali @ Mat Zin, 'Pendidikan Integratif Dalam Islam: Kesepaduan Iman, Ilmu Dan Amal', Al Muqaddimah, 2014 <https://doi.org/10.1017/CB09781107415324.004> 